\title{
Role of Oxidative Stress and Neuroinflammation in Attention-Deficit/Hyperactivity Disorder
}

\author{
Juan Carlos Corona \\ Laboratory of Neurosciences, Hospital Infantil de México Federico Gómez, Mexico City 06720, Mexico; \\ jcorona@himfg.edu.mx; Tel.: +52-55-5228-9917
}

Received: 27 July 2020; Accepted: 8 September 2020; Published: 23 October 2020

\begin{abstract}
Attention-deficit/hyperactivity disorder (ADHD) is a neurodevelopmental disorder of childhood. Although abnormalities in several brain regions and disturbances of the catecholaminergic pathway have been demonstrated, the pathophysiology of ADHD is not completely understood, but as a multifactorial disorder, has been associated with an increase in oxidative stress and neuroinflammation. This review presents an overview of factors that increase oxidative stress and neuroinflammation. The imbalance between oxidants and antioxidants and also the treatment with medications are two factors that can increase oxidative damage, whereas the comorbidity between ADHD and inflammatory disorders, altered immune response, genetic and environmental associations, and polymorphisms in inflammatory-related genes can increase neuroinflammation. Evidence of an association with these factors has become valuable for research on ADHD. Such evidence opens up new intervention routes for the use of natural products as antioxidants that could have potential as a treatment against oxidative stress and neuroinflammation in ADHD.
\end{abstract}

Keywords: oxidative stress; neuroinflammation; attention-deficit/hyperactivity disorder (ADHD); medications

\section{Introduction}

\subsection{Attention-Deficit/Hyperactivity Disorder}

Attention-deficit/hyperactivity disorder (ADHD) is a prevalent neurodevelopmental disorder in children characterized by inattention, hyperactivity, and/or impulsivity [1-3] that impairs the psychological, social, academic, and occupational function [4]. The disorder is linked with a range of comorbidities (e.g., depression, anxiety, substance use disorders, conduct disorders, criminal behavior), developmental conditions (e.g., autism spectrum disorders), and physical conditions [5-8]. Clinical diagnosis of ADHD is based on the presence of six or more symptoms that include inattention and hyperactivity/impulsivity and, according to the criteria of the fifth edition of the Diagnostic and Statistical Manual of Mental Disorders (DSM-5), should be carried out when symptoms impair academic, occupational, and social behavior, the onset is before 12 years of age and the symptoms can be observed in multiple settings in the clinical interview, including the gestational, developmental, and family history [9]. The worldwide prevalence of ADHD in children and adolescents is $7.2 \%$, with about $4 \%$ shown to persist in adults, and the diagnosis of ADHD is more frequent in boys than in girls [4,10-13]. Although ADHD is a childhood disorder, a large percentage of children continue to have symptoms in adolescent life, and approximately $45 \%$ have symptoms as adults $[1,14,15]$.

\subsection{Medications for $A D H D$}

Medications used for ADHD are divided into psychostimulants and non-psychostimulants, which have diverse delivery systems, formulations, and pharmacokinetic actions. Educational and 
psychosocial approaches are also used as a treatment for ADHD [4,16]. Psychostimulants such as methylphenidate (MPH) and amphetamine are the first-line therapy for ADHD. MPH and amphetamine improve the symptoms by blocking presynaptic dopamine and norepinephrine transporters, thus increasing catecholaminergic transmission in the striatum, prefrontal cortex, and hippocampus $[4,9,17]$. Some side effects have been observed with psychostimulants, such as insomnia, appetite loss, headache, dry mouth, anxiety, and nausea [2,18]; long-term psychostimulants treatment also has an effect on growth (particularly weight and height velocity) and causes euphoric effects and cardiovascular events $[19,20]$.

The second-line treatment is with non-psychostimulants such as atomoxetine (ATX), which is a selective norepinephrine transporter inhibitor, and selective $\alpha-2$ adrenergic receptor agonists, namely clonidine and guanfacine $[9,21,22]$. Non-psychostimulant medications usually are given to patients who cannot tolerate the side-effects of psychostimulants and have a poor response. However, some side effects of non-psychostimulants have been linked with somnolence, nausea, vomiting, diarrhea, decreased appetite, dizziness, fatigue, and changes in cardiovascular parameters [2,23].

\subsection{Etiology of $A D H D$}

The heritability of ADHD is high, with a range of 70-80\% [1,24]. Genome-wide association studies have identified approximately $22 \%$ of the heritability, associated with 12 genome-wide significant risk loci and also the enrichment of copy-number variants [25-28]. Prematurity/low birth weight and exposure to environmental toxins and pesticides have been highlighted as risk factors in ADHD [29,30]. Maternal exposure to tobacco and alcohol, nutritional deficiencies, viral infections, and obesity during pregnancy are also associated with ADHD but can also be associated with genetic factors [31].

\subsection{Pathophysiology of ADHD}

The pathophysiology related to ADHD remains unknown. However, ADHD is associated with abnormalities in the brain due to cognitive and functional deficits. Additionally, links between ADHD and the dopamine levels in specific brain regions have been found: patients with ADHD have attenuated dopaminergic activity $[32,33]$. In that sense, it has been suggested that deregulation in catecholaminergic neurotransmission is the cause of the disorder [34,35]. Furthermore, extensive data indicate the contribution of oxidative stress as a pathophysiological cause of ADHD [3,36,37]. Also, there is evidence indicating neuroinflammation as a possible factor in ADHD [3,38-40]. In this review, the role of oxidative stress and neuroinflammation as possible factors involved in the pathophysiology of ADHD is discussed, along with a possible link to the medications used for treatment that may increase these factors.

\section{Role of Oxidative Stress}

Oxidative stress is a state produced by an imbalance between antioxidants and oxidants in the cells. The imbalance occurs as a result of the inappropriate function of the antioxidant system or by an excessive level of reactive oxygen species (ROS). Oxidative stress in the brain can harm the integrity of neurons because the brain is rich in polyunsaturated fatty acids (PUFAs) that are highly susceptible to oxidation, producing ROS [41,42]. This condition could cause oxidative damage of neurons, which are rich in mitochondria; mitochondria can regulate the redox state, ion homeostasis, apoptosis, cell signaling and, as the powerhouse of the cell, produce ATP, thus they can generate ROS, causing bioenergetic disturbances that lead to cell death or several disorders, including neurodegenerative and psychiatric diseases [43-45].

Mitochondrial dysfunction, genetic, and environmental factors can generate oxidative stress, and inflammation is a neuroprotective response to diverse types of tissue damage. If the tissue is inflamed, it causes an increase of ROS, which can lead to cell death [46,47]. The oxidative stress modifies the inflammatory response, thus, when there is a redox balance, the inflammatory response is a defense mechanism; when there is a redox imbalance, the signaling pathways that modulate 
the immune system are altered, leading to dysregulation of the immune response [48]. In a chronic state of oxidative stress, proteins and lipids oxidize and the DNA is damaged. ROS could also lead to the activation of astrocytes and microglia. High concentrations of ROS could activate the high secretion of proinflammatory chemokines and cytokines and produce a vicious circle $[47,48]$. Therefore, oxidative stress and neuroinflammation are mechanisms that coexist and are interrelated. The pathophysiology of ADHD is associated with oxidative stress and neuroinflammation, due to the imbalance between oxidants and antioxidants, catecholaminergic dysregulation, medications used for treatment, genetic and environmental factors, and all those factors could be producing oxidative stress and neuroinflammation which further increases the symptoms and as a result, triggering a vicious circle.

\subsection{Oxidative Stress and Oxidant Levels}

Numerous studies have demonstrated elevated levels of oxidative stress in ADHD, increasing the evidence for oxidative stress being a pathophysiological factor. The measurement of higher rates of ethane levels, as a non-invasive measure of oxidative breakdown of n-3 PUFAs in patients with ADHD, was also demonstrated [49]. Furthermore, elevated levels of malondialdehyde (MDA) have been observed in children with ADHD [50,51]. A randomized, double-blind, placebo-controlled study found that children with ADHD had increased damage to DNA, measured with 8-oxo-7,8-dihydroguanine (8-oxoG) [52]. Moreover, the levels of MDA in plasma from children and adolescents with ADHD were significantly higher than the controls [53]. An increase in lipid peroxidation in pediatric ADHD patients was evaluated using acrolein-lysine in urine samples [54]. Also, changes in plasma levels of xanthine oxidase $(\mathrm{XO})$ were significantly higher in patients with ADHD [55]. The levels of MDA and the DNA damage indicator 8-hydroxy-2'-deoxyguanosine (8-OHdG) were statistically lower in children with ADHD [56,57]. The total oxidative status (TOS) and oxidative stress index (OSI) were higher in patients with ADHD than controls [58]. Furthermore, in children and adolescents with ADHD, the TOS and OSI were significantly higher than in healthy controls [59]. Also, the TOS was high in plasma of children and adolescents with ADHD [60]. In a meta-analysis of ADHD patients, an increase in oxidative stress was found [37]. Moreover, TOS and OSI were increased in children with ADHD [61]. No significant differences were detected in serum TOS and OSI levels in adults with ADHD [62]. Also, in the spontaneously hypertensive rat (SHR), used as an animal model for ADHD, an increase in ROS production measured using $2^{\prime}-7^{\prime}$-dichlorofluorescein diacetate (DCFH-DA) was demonstrated in the striatum, hippocampus, and cortex [63]. In contrast, it was demonstrated that MDA levels were not significantly different in children with ADHD [64]. Moreover, in children with ADHD, increases in plasma MDA and urinary 8-OHdG levels were found [65]. Finally, the levels of MDA and free sulphydryl groups in the spleen were higher in 5-week-old SHR than in control rats [66]. Recently, evaluation of serum levels of hydroperoxide, an oxidative stress marker, was shown to be higher in preschool children with ADHD [67].

\subsection{Nitrosative Stress}

An increase in nitrosative stress (i.e., nitric oxide (NO) levels) and an impaired balance of oxidants and antioxidants were observed in children with ADHD [68]. In the SHR, damaged non-selective attention was improved with the nitric oxide synthase (NOS) inhibitor L-nitro-arginine methyl ester (L-NAME) [69]. In contrast, reduced blood NO levels have been reported [70]. On the other hand, NO levels were significantly higher in ADHD [53,71]. Also, changes in plasma levels of NOS were significantly higher in patients with ADHD [55]. The outcomes of oxidative and nitrosative stress are summarized in Table 1. 
Table 1. Summary of oxidative and nitrosative stress biomarkers and outcomes.

\begin{tabular}{|c|c|c|}
\hline Biomarker/Outcome & $\begin{array}{l}\text { Sample Compared to } \\
\text { Control/Treatment }(T x)\end{array}$ & Reference \\
\hline Improved non-selective attention & Rat intraperitoneal NOS inhibitor & [69] \\
\hline$\uparrow$ Extracellular norepinephrine and dopamine in PC & Rat brain-Tx ATX & [22] \\
\hline Breakdown of PUFAs & $\uparrow$ exhaled ethane & [49] \\
\hline $\begin{array}{c}\uparrow \text { Extracellular norepinephrine and dopamine in PC, } \\
\text { OC, HPT, HC, and CB }\end{array}$ & Rat brain-Tx ATX & [72] \\
\hline $\mathrm{NO}$ & $\downarrow$ Plasma & [70] \\
\hline$\uparrow$ TBARS and protein carbonyl formation & Rat brain regions-Tx $\mathrm{MPH}$ & [73] \\
\hline $8-\mathrm{oxoG}$ & $\uparrow$ Plasma & [52] \\
\hline$\uparrow$ DNA damage & $\begin{array}{l}\text { Rat blood and brain regions-Tx } \\
\text { MPH }\end{array}$ & [74] \\
\hline$\uparrow$ Mitochondrial complexes & Rat brain homogenates-Tx MPH & [75] \\
\hline MDA & $\uparrow$ Plasma & {$[50]$} \\
\hline MDA & $\downarrow$ Plasma & [57] \\
\hline $\mathrm{NO}$ & $\uparrow$ Plasma & {$[71]$} \\
\hline $\begin{array}{l}\uparrow \text { Superoxide in submitochondrial particles in CB and } \\
\text { HC }\end{array}$ & Rat brain-Tx MPH & [76] \\
\hline MDA and NO & $\uparrow$ Plasma & [53] \\
\hline Acrolein-lysine & $\uparrow$ Urine & [54] \\
\hline TOS and OSI & $\uparrow$ Plasma & [58] \\
\hline MDA and 8-OHdG & $\downarrow$ Plasma & [56] \\
\hline $\mathrm{XO}$ and NOS & $\uparrow$ Serum & [55] \\
\hline $\begin{array}{c}\downarrow \text { TBARS and reactive species level in HC and ST } \\
\uparrow \text { Reactive species level and lipid peroxidation in PC }\end{array}$ & Rat brain homogenates-Tx MPH & [77] \\
\hline $\mathrm{MDA}^{1}$ & $\uparrow$ Plasma & [51] \\
\hline$\uparrow$ TBARS and carbonyl groups & Rat brain homogenates-Tx MPH & [78] \\
\hline TOS and OSI & $\uparrow$ Plasma & [59] \\
\hline TOS & $\uparrow$ Plasma & {$[60]$} \\
\hline TOS and OSI & $\uparrow$ Serum & [61] \\
\hline $\begin{array}{l}\uparrow \mathrm{MDA} \text { and induced neurodegeneration in CC and } \\
\mathrm{HC}\end{array}$ & Rat brain homogenates-Tx MPH & [79] \\
\hline DCFH-DA & $\uparrow$ Rat brain homogenates & [63] \\
\hline TOS and OSI & $=$ Serum & {$[62]$} \\
\hline MDA & $=$ Serum & [64] \\
\hline MDA and 8-OHdG & $\uparrow$ Plasma and urine & {$[65]$} \\
\hline MDA and free sulphydryl groups & $\uparrow$ Rat spleen & [66] \\
\hline $\begin{array}{l}\text { Impaired oxidants-antioxidants balance } \\
\uparrow \uparrow \mathrm{NO}\end{array}$ & Serum & {$[68]$} \\
\hline $\begin{array}{l}\uparrow \text { Cytosolic and mitochondrial ROS, damage of } \\
\text { mitochondria and cell death }\end{array}$ & Cell line-Tx ATX & [80] \\
\hline MDA in CX and $\mathrm{HC}$ & $\uparrow$ Rat brain homogenates- $\mathrm{Tx} \mathrm{MPH}$ & [81] \\
\hline Hydroperoxide & $\uparrow$ Serum & {$[67]$} \\
\hline
\end{tabular}

The table summarizes the oxidative and nitrosative stress biomarkers and outcomes. More details in the text. PC, prefrontal cortex; HC, hippocampus; OC, occipital cortex; CB, cerebellum; ST, striatum; HPT, hypothalamus; CC, cerebral cortex; CX, cortex; $\uparrow$, increased; $\downarrow$, decreased; =, no difference.

\subsection{Antioxidant Levels in ADHD}

In a randomized, double-blind, placebo-controlled study, it was found that children with ADHD had decreased total antioxidant status (TAS) [52]. Also, the TAS in children with ADHD was low [82]. Moreover, in a randomized, double-blind controlled trial, higher concentrations of adrenaline and noradrenaline were found in the urine of ADHD patients, which correlated positively with the degree of hyperactivity, and they were associated with high levels of oxidized glutathione disulphide (GSSG), which is an important marker of exhaustion of the antioxidant glutathione (GSH) [83]. In plasma samples of patients with ADHD, the antioxidant enzyme activity of glutathione peroxidase (GPx) was significantly lower, the superoxide dismutase (SOD) activity was not significantly different between 
patients and controls, and the catalase (CAT) activity was higher than in the controls, but not statistically significant [53]. It was also demonstrated that the serum levels of SOD1 were significantly lower in children with ADHD [84]. Moreover, in plasma, the levels of SOD, glutathione-S-transferase (GST), GPx, and CAT were significantly lower in children with ADHD [85]. Furthermore, a decrease in the salivary total antioxidant activity was observed in children with ADHD [86]. It has been demonstrated that levels of the antioxidant enzymes GST and paraoxonase-1 (PON1) were significantly lower in plasma from patients with ADHD [55], however, the antioxidant PON1 and thiol levels were no different in children with ADHD [56]. In addition, a significant increase in the salivary thiol levels was observed; in contrast, ceruloplasmin, which is an important extracellular antioxidant, did not show any significant change, but magnesium levels were significantly decreased in children with ADHD [87]. The TAS was increased in patients with ADHD [58], but TAS levels in plasma tended to decrease in children and adolescents with ADHD, and antioxidant enzymes such as PON, stimulated PON, and arylesterase (ARE) showed no differences in activity. However, a significantly lower thiol enzyme activity was found in the plasma of children and adolescents with ADHD [60]. TAS was also significantly lower in children and adolescents with ADHD than in controls [59]. In children with ADHD, it was demonstrated that the TAS, PON1, and ARE activities were decreased [61]. In the SHR, decreased GPx activity was found in the prefrontal cortex, but there was no difference in the other regions or in GSH, SOD, and CAT activities between the SHR and controls [63]. In adults with ADHD, the homocysteine level was lower and the serum folate level was higher. However, no significant difference was detected in serum vitamin B12 and the TAS [62]. In contrast, erythrocyte GSH and plasma retinyl palmitate levels were higher in patients with ADHD than in controls [65]. The antioxidant levels of melatonin were high in serum from children with ADHD [68]. Finally, the total antioxidant capacity (TAC), CAT, and GSH were significantly lower in children with ADHD [64]. Some of the opposing results observed in the different studies could be explained by the different methodologies, the participant selection criteria and the analysis used. Thus, the extensive data propose that a decrease in antioxidants and an increase in both oxidative and nitrosative stress in ADHD could contribute to its pathophysiology [3,36,37]. The antioxidant outcomes of are summarized in Table 2.

Table 2. Summary of antioxidant biomarkers and outcomes.

\begin{tabular}{|c|c|c|}
\hline Biomarker/Outcome & $\begin{array}{l}\text { Sample Compared to } \\
\text { Control/Treatment (Tx) }\end{array}$ & Reference \\
\hline TAS & $\downarrow$ Plasma & [52] \\
\hline TAS & $\downarrow$ Plasma & [82] \\
\hline $\begin{array}{c}\uparrow \text { Adrenaline and noradrenaline } \\
\uparrow \text { GSSG level and } \downarrow \text { GSH level }\end{array}$ & Plasma & [83] \\
\hline $\begin{array}{c}\text { SOD (chronic Tx: } \uparrow \text { CC, HC, and } \downarrow \text { ST-acute Tx: } \uparrow \text { CC } \\
\text { and } \downarrow \text { PC) }\end{array}$ & Rat brain-Tx MPH & [88] \\
\hline CAT (acute Tx: $\downarrow$ HC) & & \\
\hline SOD & $\downarrow$ Plasma & [71] \\
\hline$\uparrow \mathrm{CAT}, \downarrow \mathrm{GPx}$ and $=\mathrm{SOD}$ & Plasma & [53] \\
\hline SOD1 & $\downarrow$ Serum & [84] \\
\hline SOD, GST, GPx, and CAT & $\downarrow$ Plasma & [85] \\
\hline Antioxidant activity and CAT & $\downarrow$ Saliva & [86] \\
\hline GST, PON1 & $\downarrow$ Serum & [55] \\
\hline PON1 and thiol & $=$ Plasma & [56] \\
\hline$=$ Ceruloplasmin and $\uparrow$ thiol & Saliva & [87] \\
\hline TAS & $\uparrow$ Plasma & [58] \\
\hline$\uparrow \mathrm{SOD}$ and CAT in CB & Rat brain homogenates-Tx MPH & [77] \\
\hline PON1 and ARE & $\downarrow$ Plasma & [51] \\
\hline$\downarrow$ SOD and CAT & Rat brain homogenates-Tx MPH & [78] \\
\hline TAS & $\downarrow$ Plasma & [59] \\
\hline $\begin{array}{l}\downarrow \text { TAS and thiol } \\
=\mathrm{PON} \text { and } \mathrm{ARE}\end{array}$ & Plasma & {$[60]$} \\
\hline TAS, PON1, and ARE & $\downarrow$ Serum & {$[61]$} \\
\hline
\end{tabular}


Table 2. Cont.

\begin{tabular}{ccc}
\hline Biomarker/Outcome & $\begin{array}{c}\text { Sample Compared to } \\
\text { Control/Treatment (Tx) }\end{array}$ & Reference \\
\hline$\downarrow$ GSH, SOD, GPx, and GR in CC and HC & Rat brain homogenates-Tx MPH & {$[79]$} \\
$=$ GSH, SOD, and CAT & Rat brain homogenates & {$[63]$} \\
$\downarrow$ GPx in PC & Serum & {$[62]$} \\
$=$ Vomocysteine and $\uparrow$ Folate & $\uparrow$ Plasma and erythrocytes & {$[65]$} \\
Retinyl palmitate and GSH & $\downarrow$ Serum & {$[64]$} \\
TAC, CAT, and GSH & $\uparrow$ Serum & {$[68]$} \\
SOD in CX and HC & $\downarrow$ Rat brain homogenates-Tx MPH & {$[81]$} \\
\hline
\end{tabular}

The table summarizes the antioxidant biomarkers and outcomes. More details in the text. PC, prefrontal cortex; HC, hippocampus; CB, cerebellum; ST, striatum; CC, cerebral cortex; CX, cortex. $\uparrow$, increased; $\downarrow$, decreased; $=$, no difference.

As demonstrated in Tables 1 and 2, data on oxidative, nitrosative stress, and antioxidant levels are inconsistent in patients with ADHD. Altogether, some differences have been observed, although the changes are controversial, suggesting that patients with ADHD have heterogeneity in the antioxidant production, but their response to oxidative and nitrosative stress is insufficient, leading to oxidative damage. Thus, studies carried out so far point out that ADHD is associated with increased oxidative stress. However, there continues to be inconsistency in findings, and this may at least be partly attributed to differences in participants examined, oxidative stress markers tested, and protocols and samples utilized to examine appropriate markers. It is also acceptable that oxidative stress is associated with some ADHD symptoms and/or subtypes, across gender and age, but this has not yet been enough explored due to a lack of appropriate research. Consequently, methodological differences might underlie contradictory results. Additional research is therefore required to help clarify the importance of oxidative stress in ADHD and its pertinence for the treatment and prevention of ADHD.

\subsection{ADHD Medications and Oxidative Damage}

It has been demonstrated that treatment with MPH increases the generation of oxidative stress; in the brain of young rats, chronic treatment with MPH increased oxidative stress as assessed by thiobarbituric acid reactive species (TBARS) and protein carbonyl formation [73]. Also, treatment with $\mathrm{MPH}$ in the striatum of young and adult rats increases DNA damage [74]. On the other hand, it was demonstrated that chronic exposure to $\mathrm{MPH}$ in the brain of young rats increases mitochondrial complexes [75]. Moreover, chronic or acute treatment with MPH altered the activity of SOD and CAT enzymes in the brain of young rats [88]. Acute administration of MPH in young rats increased the production of superoxide in submitochondrial particles in the cerebellum and hippocampus [76]. Additionally, in the prefrontal cortex of juvenile rats, chronic MPH treatment induced an increase in oxidative stress, protein damage, and lipid peroxidation [77]. Furthermore, an increase in oxidative stress was shown with acute and chronic MPH treatment in the SHR [78]. Finally, acute administration of high doses of MPH in adult rats produced oxidative damage, reduced GSH, SOD, GPx, and glutathione reductase (GR) activities, and provoked neurodegeneration in the cerebral cortex and hippocampus [79]. Recently, in the cortex and hippocampus of rats treated with MPH, MDA levels were increased and SOD levels reduced [81].

The auto-oxidation of catecholamines (dopamine and norepinephrine) can be easily generated and ROS formed [89-91]; ROS generation can trigger oxidative damage to DNA and cell death [92,93]. In that sense, it was demonstrated that ATX treatment increases extracellular catecholamine levels [22,72]. Therefore, ATX can trigger an increase of cytosolic and mitochondrial ROS, producing damage to the mitochondria and consequently, cell death [80]. The precise association between the auto-oxidation of catecholamines and the generation of oxidative stress in ADHD remains unclear. Hence, both processes could be implicated in the pathophysiology of ADHD. 


\section{Role of Neuroinflammation}

The innate and adaptive immune systems work in harmony to support and determine effective and protective immune responses. The innate immune system works as the first line of defense, including the clearance of microbes such as viruses or bacteria, wound repair, and removal of cells that are in the process of dying. Moreover, the innate immune system can later activate the adaptive system. The cells in the central nervous system that participate in the innate immune response are microglia (which are immune cells in the brain), astrocytes, mast cells, natural killer cells, macrophages and oligodendrocytes, circulating phagocytes, and also monocytes, which are the precursors of macrophages and dendritic cells and play a role in innate immunity $[94,95]$. The adaptive immune system is highly specific and capable of remembering; it can also effectively initiate responses against previously experienced immunological threats or eliminate tumors. The components of the adaptive immune system are the T and B cells, known as lymphocytes, the effector cells, and their secreted products $[94,95]$.

Inflammation of the nervous system, commonly known as neuroinflammation, can be characterized by the activation of microglia (which play a role in pathological and physiological conditions), astrocytes, oligodendrocytes, and ependymal cells, by increasing levels of proteases, glutamate, ROS, $\mathrm{NO}$, chemokines, toxic cytokines, and prostaglandins and by infiltration of $\mathrm{T}$ and $\mathrm{B}$ cells, neutrophils, monocytes/macrophages and dendritic cells [96-99]. The role of neuroinflammation has been associated with several neuropsychiatric disorders, such as autism [100], bipolar disorder [101], depression [102], and schizophrenia [103]. Thus, growing interest points to neuroinflammation as a factor involved in the pathophysiology of ADHD [3,39,40].

Microglia represents the resident immune cells of the CNS, with an important function in the elimination of waste products during inflammation or damage [94]. The cytokine and growth factor S100B is a marker of glial function. In serum samples of children with ADHD, there were no clear differences in the levels of S100B [104]. Conversely, a decreased in the total serum levels of S100B were modestly associated with hyperactive-impulsive symptoms [105].

Astrocytes have unique functional and morphological characteristics that differ within specific areas of the brain, and brain disorders could be characterized by an inflammatory state of the astrocytes. Thus, astrocytes can drive the induction and progression of the inflammatory state, which is notably related to the disorder condition or severity [106]. SynCAM1 is an adhesion molecule involved in synaptic differentiation and organization, which is expressed in astroglial cells. A mice carrying a dominant-negative form of SynCAM1 specifically targeted to astrocytes developed behavioral abnormalities similar to those described in animals model of ADHD, suggesting unappreciated involvement of astrocytes to the pathophysiology of this disorder [107].

An association between cytokines and ADHD symptoms in children has been demonstrated. As a result, elevated levels of IL-16 (hyperactive-impulsive symptoms) and IL-13 (inattention) were found [105]. In patients with ADHD, the adenosine deaminase (ADA) activity, a marker of cellular immunity, was significantly higher; ADA has a role in differentiation and lymphocyte proliferation [55]. Furthermore, it has been suggested that the release of inflammatory cytokines caused by stress or allergic inflammation could alter the maturation of the prefrontal cortex and the neurotransmitters involved in ADHD [108]. Additionally, serum levels of IL-6 were significantly higher in children with ADHD compared with controls [109]. The serum and splenic concentrations of chemokines IP-10, RANTES, and MCP-1 were significantly increased in 5- and 10-week-old SHR, and increased levels of IL-6 and TNF- $\alpha$ were observed in 5-week-old SHR [66]. Recently, in plasma from young people with ADHD, higher levels of C-reactive protein and IL- 6 and lower levels of TNF- $\alpha$ and BDNF were found [110]. 


\subsection{Inflammation and Polymorphisms}

The contribution of gene polymorphisms could be associated as a neurodevelopmental risk factor in the pathogenesis of ADHD. Thus, the findings of the IL-1 receptor antagonist (IL-1RA) gene variable number tandem repeat (VNTR) polymorphism in children with ADHD demonstrated that the 2-repeat allele was associated with reduced risk and the 4-repeat allele with increased risk for ADHD [111]. Nevertheless, no evidence for the association of IL-1RA polymorphism with ADHD was found [112]. Furthermore, a significantly higher polymorphism of dopamine receptor D2 gene (TaqI A) and of BDNF (196 G/A val66met), IL-2 (-330), IL-6 (-174), and TNF- $\alpha$ (-308) was reported [113]. In a study of single nucleotide polymorphisms (SNPs) an association was demonstrated between the cytokine family and the ciliary neurotrophic factor receptor (CNTF) in both adults and children with ADHD, (rs7036351, rs1080750 and rs1124882 risk haplotypes) [114]. Also, two SNPs in the CNTF (rs10758268 and rs7044318) gene were associated with inattentive symptom severity in ADHD and SNPs within cytokine genes IL-16 (rs8039027), and S100B (rs2839361) moderated the association between birthweight and symptom severity [115]. The outcomes of neuroinflammation are summarized in Table 3.

Table 3. Summary of neuroinflammation and outcomes in ADHD.

\begin{tabular}{|c|c|c|}
\hline Type of Study & Outcome & References \\
\hline DNA from children & IL-1RA: 2 -repeat allele $\downarrow$ risk and 4-repeat allele $\uparrow$ risk & [111] \\
\hline DNA from children & No evidence of IL-1RA polymorphism & [112] \\
\hline DNA from children & $\begin{array}{c}\uparrow \text { Polymorphism of dopamine receptor D2, BDNF, } \\
\text { IL-2, IL- } 6 \text { and TNF- } \alpha\end{array}$ & [113] \\
\hline DNA from children and adults & Association with CNTF & [114] \\
\hline Serum from children & $\begin{array}{c}\uparrow \text { Levels of IL-16 and IL-13 } \\
\downarrow \text { S100B associated with hyperactive-impulsive } \\
\text { symptoms }\end{array}$ & [105] \\
\hline A cross-sectional study of adults & $\uparrow$ Comorbidity with asthma & [116] \\
\hline Serum from children & $\uparrow$ ADA activity & [55] \\
\hline $\begin{array}{l}\text { Astrocyte-specific disruption of } \\
\text { SynCAM1 }\end{array}$ & ADHD-like behavior abnormalities in mice & [107] \\
\hline Serum from children & $\begin{array}{l}\text { Positive immunoreactivity against anti-Purkinje cell } \\
\text { antibodies in the cerebellum }\end{array}$ & [117] \\
\hline $\begin{array}{l}\text { Birth cohort, population-based } \\
\text { and correlational studies of } \\
\text { children and adolescents }\end{array}$ & $\uparrow$ Comorbidity with atopic eczema & {$[108,118,119]$} \\
\hline DNA from young & $\begin{array}{l}\text { 2 SNPs in CNTF were associated } \\
\text { SNPs within IL-16 and S100B moderated birthweight } \\
\text { and symptom severity }\end{array}$ & [115] \\
\hline $\begin{array}{l}\text { A population-based cohort study } \\
\text { using a sibling-comparison design }\end{array}$ & $\begin{array}{l}\text { Maternal obesity and metabolic complications could } \\
\text { increase the risk of ADHD in offspring }\end{array}$ & {$[120,121]$} \\
\hline Serum from patients & $\begin{array}{l}\text { Autoimmune reactions against the basal ganglia and } \\
\text { streptococcal infections }\end{array}$ & {$[122,123]$} \\
\hline Serum from children & $\uparrow$ Auto-antibodies against the dopamine transporter & [124] \\
\hline Serum from patients & $\uparrow$ Anti-basal ganglia antibodies & [122] \\
\hline Serum from children & $\uparrow$ Anti-Purkinje antibodies and IL-6 and IL-10 & [125] \\
\hline Population-based study of patients & $\begin{array}{l}\uparrow \text { Prevalence of autoimmune thyroid disease, } \\
\text { ulcerative colitis, and ankylosing spondylitis }\end{array}$ & [126] \\
\hline $\begin{array}{l}\text { Population-based nested } \\
\text { case-control study }\end{array}$ & $\begin{array}{c}\text { Mothers with inflammatory or immune diseases } \uparrow \\
\text { risk of ADHD in offspring }\end{array}$ & [38] \\
\hline A prospective nationwide study & $\begin{array}{c}\text { Maternal history of autoimmune disease could } \uparrow \text { risk } \\
\text { of ADHD }\end{array}$ & [127] \\
\hline $\begin{array}{l}\text { Population-based case-control, } \\
\text { large-scale cross-sectional, } \\
\text { population-based studies, and } \\
\text { venous blood of children }\end{array}$ & $\begin{array}{l}\uparrow \text { Comorbidity with allergic diseases such as allergic } \\
\text { rhinitis, atopic dermatitis, allergic conjunctivitis }\end{array}$ & [128-132] \\
\hline
\end{tabular}


Table 3. Cont.

\begin{tabular}{|c|c|c|}
\hline Type of Study & Outcome & References \\
\hline Serum from children & $\uparrow$ IL-6 & [109] \\
\hline Serum and spleen from SHR & $\begin{array}{l}\uparrow \text { IP-10, RANTES, and MCP-1 } \\
\uparrow \text { Levels of IL- } 6 \text { and TNF- } \alpha\end{array}$ & [66] \\
\hline $\begin{array}{l}\text { Large-scale genome-wide } \\
\text { cross-trait association study }\end{array}$ & Causal links between asthma and ADHD & [133] \\
\hline Plasma from young & $\uparrow$ C-reactive protein and IL- 6 and $\downarrow$ TNF- $\alpha$ and BDNF & [110] \\
\hline $\begin{array}{l}\text { Prenatal studies with a nested } \\
\text { case-control design }\end{array}$ & $\begin{array}{l}\text { Maternal C-reactive protein during early pregnancy } \\
\text { showed no significant association in offspring }\end{array}$ & [134] \\
\hline
\end{tabular}

The table summarizes the neuroinflammation and outcomes. More details in the text. $\uparrow$, increased; $\downarrow$, decreased.

\subsection{Antibodies in $A D H D$}

A possible association between specific antibodies and immune dysregulation in ADHD has been evaluated and a significant positive immunoreactivity against anti-Purkinje cell antibodies in the cerebellum of children with ADHD was found [117]. Furthermore, a high percentage of anti-Purkinje antibodies and increased serum levels of interleukin IL-6 and IL-10 were detected in patients with ADHD [125]. Moreover, high levels of auto-antibodies against the dopamine transporter [124] and high levels of anti-basal ganglia antibodies were found in ADHD patients [122].

\subsection{Comorbidity with Other Disorders}

A marked comorbidity has been observed between ADHD and asthma [116], atopic eczema $[108,118,119]$, and allergic diseases such as allergic rhinitis, atopic dermatitis, and allergic conjunctivitis [128-132]. Moreover, it was indicated that autoimmune reactions against the basal ganglia and streptococcal infections are more frequent in patients with ADHD [122,123]. The comorbidity of autoimmune diseases with ADHD was demonstrated to be low, but patients with ADHD had a significant prevalence of autoimmune thyroid disease, ulcerative colitis, and ankylosing spondylitis compared to controls [126]. Recently, a large-scale genome-wide cross-trait analysis identified causal links between asthma and ADHD [133]. Thus, more research is required to elucidate the comorbidity between ADHD and allergic or autoimmune disorders.

Both maternal obesity and metabolic complications could increase the risk of ADHD in offspring [120,121]. Moreover, the risk of ADHD in offspring has been found to increase in mothers with inflammatory or immune diseases [38]. Furthermore, a maternal history of autoimmune disease could be associated with an increased risk of ADHD [127], but recently, the maternal C-reactive protein during early pregnancy showed no significant associations with ADHD in offspring [134].

\section{Use of Dietary and Natural Compounds against Oxidative Stress and Neuroinflammation in ADHD}

Increasing studies are looking for alternative therapies for ADHD, mainly focused on the neuroprotective effects of dietary and natural compounds as antioxidants because they may be alternative treatments with fewer side effects. Some nutritional or natural components which have been studied for having therapeutic benefits in ADHD are: Omega-3 fatty acids have antioxidant and anti-inflammatory activities and the two main are docosahexaenoic acid and eicosapentaenoic acid, found mainly in oily fish [3,135-137]. N-Acetylcysteine is a precursor of the antioxidant glutathione, found in the onion and exerts antioxidant and anti-inflammatory activities [3,135]. Sulforaphane exerts antioxidant and anti-inflammatory activities, is found in highest concentrations in broccoli sprouts, and cauliflower [3]. Ginseng contains a class of phytochemicals called ginsenosides, known as potent antioxidants [2,136]. St. John's wort, which is rich in flavonoids, providing antioxidants effects [2]. Passionflower contains flavonoids and exerts antioxidants activities [2]. Ginkgo biloba has antioxidant effects and contains flavonoids, terpenoids, and ginkgolic acid $[2,135,136]$. Several flavonoids with 
antioxidant activities that include a large group of natural polyphenols are found abundantly in fruits, red wine, green tea, and vegetables $[2,135,136]$. Thus, it has been shown that these compounds could improve ADHD progression due to their antioxidants and anti-inflammatory properties.

\section{Conclusions}

The pathophysiological process of ADHD has been associated with an increase in oxidative stress and neuroinflammation. Accordingly, some of the factors discussed in this review appear to play a key role in the pathological process of ADHD. Several factors seem to increase oxidative stress, such as the imbalance between oxidants and antioxidants in patients and also the treatment with medications, both of which could increase the oxidative damage in patients. Moreover, several factors can also cause neuroinflammation in ADHD, such as an altered immune response, genetic and environmental associations, comorbidity between ADHD and inflammatory disorders, and also some polymorphisms in inflammatory-related genes. The aforementioned factors offer the potential for dietary and natural compounds as ADHD therapy, due to the potent antioxidant and anti-inflammatory properties such as the increase of antioxidant levels, reduce oxidative stress, and improve the inflammation. In summary, there are several pieces of evidence for the role of oxidative stress and neuroinflammation in the pathophysiology of ADHD. However, clinical trials and prospective, well-designed studies are still needed to confirm these hypotheses.

Funding: This work was supported by Fondos Federales HIM 2018/030 SSA 1497.

Conflicts of Interest: The author declares no conflict of interest.

\section{References}

1. Faraone, S.V.; Asherson, P.; Banaschewski, T.; Biederman, J.; Buitelaar, J.K.; Ramos-Quiroga, J.A.; Rohde, L.A.; Sonuga-Barke, E.J.; Tannock, R.; Franke, B. Attention-deficit/hyperactivity disorder. Nat. Rev. Dis. Primers 2015, 1, 15020. [CrossRef]

2. Corona, J.C. Natural Compounds for the Management of Parkinson's Disease and Attention-Deficit/ Hyperactivity Disorder. Biomed. Res. Int. 2018, 2018, 4067597. [CrossRef] [PubMed]

3. Alvarez-Arellano, L.; Gonzalez-Garcia, N.; Salazar-Garcia, M.; Corona, J.C. Antioxidants as a Potential Target against Inflammation and Oxidative Stress in Attention-Deficit/Hyperactivity Disorder. Antioxidants 2020, 9, 176. [CrossRef]

4. Wolraich, M.L.; Hagan, J.F., Jr.; Allan, C.; Chan, E.; Davison, D.; Earls, M.; Evans, S.W.; Flinn, S.K.; Froehlich, T.; Frost, J.; et al. Clinical Practice Guideline for the Diagnosis, Evaluation, and Treatment of Attention-Deficit/Hyperactivity Disorder in Children and Adolescents. Pediatrics 2019, 144, e20192528. [CrossRef]

5. Jensen, P.S.; Hinshaw, S.P.; Kraemer, H.C.; Lenora, N.; Newcorn, J.H.; Abikoff, H.B.; March, J.S.; Arnold, L.E.; Cantwell, D.P.; Conners, C.K.; et al. ADHD comorbidity findings from the MTA study: Comparing comorbid subgroups. J. Am. Acad. Child. Adolesc. Psychiatry 2001, 40, 147-158. [CrossRef] [PubMed]

6. Tejeda-Romero, C.; Kobashi-Margain, R.A.; Alvarez-Arellano, L.; Corona, J.C.; Gonzalez-Garcia, N. Differences in substance use, psychiatric disorders and social factors between Mexican adolescents and young adults. Am. J. Addict. 2018, 27, 625-631. [CrossRef] [PubMed]

7. Newcorn, J.H.; Halperin, J.M.; Jensen, P.S.; Abikoff, H.B.; Arnold, L.E.; Cantwell, D.P.; Conners, C.K.; Elliott, G.R.; Epstein, J.N.; Greenhill, L.L.; et al. Symptom profiles in children with ADHD: Effects of comorbidity and gender. J. Am. Acad. Child. Adolesc. Psychiatry 2001, 40, 137-146. [CrossRef] [PubMed]

8. Yoshimasu, K.; Barbaresi, W.J.; Colligan, R.C.; Voigt, R.G.; Weaver, A.L.; Katusic, S.K. Mediating and Moderating Role of Depression, Conduct Disorder or Attention-Deficit/Hyperactivity Disorder in Developing Adolescent Substance Use Disorders: A Population-Based Study. PLoS ONE 2016, 11, e0157488. [CrossRef]

9. Posner, J.; Polanczyk, G.V.; Sonuga-Barke, E. Attention-deficit hyperactivity disorder. Lancet 2020, 395, 450-462. [CrossRef]

10. Polanczyk, G.; de Lima, M.S.; Horta, B.L.; Biederman, J.; Rohde, L.A. The worldwide prevalence of ADHD: A systematic review and metaregression analysis. Am. J. Psychiatry 2007, 164, 942-948. [CrossRef] 
11. Sayal, K.; Prasad, V.; Daley, D.; Ford, T.; Coghill, D. ADHD in children and young people: Prevalence, care pathways, and service provision. Lancet Psychiatry 2018, 5, 175-186. [CrossRef]

12. Willcutt, E.G. The prevalence of DSM-IV attention-deficit/hyperactivity disorder: A meta-analytic review. Neurotherapeutics 2012, 9, 490-499. [CrossRef]

13. Caye, A.; Spadini, A.V.; Karam, R.G.; Grevet, E.H.; Rovaris, D.L.; Bau, C.H.; Rohde, L.A.; Kieling, C. Predictors of persistence of ADHD into adulthood: A systematic review of the literature and meta-analysis. Eur. Child. Adolesc. Psychiatry 2016, 25, 1151-1159. [CrossRef] [PubMed]

14. Wilens, T.E.; Faraone, S.V.; Biederman, J. Attention-deficit/hyperactivity disorder in adults. JAMA 2004, 292, 619-623. [CrossRef] [PubMed]

15. Wilens, T.E.; Spencer, T.J. Understanding attention-deficit/hyperactivity disorder from childhood to adulthood. Postgrad. Med. 2010, 122, 97-109. [CrossRef]

16. Geffen, J.; Forster, K. Treatment of adult ADHD: A clinical perspective. Ther. Adv. Psychopharmacol. 2018, 8, 25-32. [CrossRef]

17. Koda, K.; Ago, Y.; Cong, Y.; Kita, Y.; Takuma, K.; Matsuda, T. Effects of acute and chronic administration of atomoxetine and methylphenidate on extracellular levels of noradrenaline, dopamine and serotonin in the prefrontal cortex and striatum of mice. J. Neurochem. 2010, 114, 259-270. [CrossRef] [PubMed]

18. Clemow, D.B. Misuse of Methylphenidate. Curr. Top. Behav. Neurosci. 2017, 34, 99-124.

19. Swanson, J.M.; Elliott, G.R.; Greenhill, L.L.; Wigal, T.; Arnold, L.E.; Vitiello, B.; Hechtman, L.; Epstein, J.N.; Pelham, W.E.; Abikoff, H.B.; et al. Effects of stimulant medication on growth rates across 3 years in the MTA follow-up. J. Am. Acad. Child. Adolesc. Psychiatry 2007, 46, 1015-1027. [CrossRef]

20. Greenhill, L.L.; Swanson, J.M.; Hechtman, L.; Waxmonsky, J.; Arnold, L.E.; Molina, B.S.G.; Hinshaw, S.P.; Jensen, P.S.; Abikoff, H.B.; Wigal, T.; et al. Trajectories of Growth Associated With Long-Term Stimulant Medication in the Multimodal Treatment Study of Attention-Deficit/Hyperactivity Disorder. J. Am. Acad. Child. Adolesc. Psychiatry 2019. [CrossRef]

21. Cinnamon Bidwell, L.; Dew, R.E.; Kollins, S.H. Alpha-2 adrenergic receptors and attention-deficit/ hyperactivity disorder. Curr. Psychiatry Rep. 2010, 12, 366-373. [CrossRef] [PubMed]

22. Bymaster, F.P.; Katner, J.S.; Nelson, D.L.; Hemrick-Luecke, S.K.; Threlkeld, P.G.; Heiligenstein, J.H.; Morin, S.M.; Gehlert, D.R.; Perry, K.W. Atomoxetine increases extracellular levels of norepinephrine and dopamine in prefrontal cortex of rat: A potential mechanism for efficacy in attention deficit/hyperactivity disorder. Neuropsychopharmacology 2002, 27, 699-711. [CrossRef]

23. Reed, V.A.; Buitelaar, J.K.; Anand, E.; Day, K.A.; Treuer, T.; Upadhyaya, H.P.; Coghill, D.R.; Kryzhanovskaya, L.A.; Savill, N.C. The Safety of Atomoxetine for the Treatment of Children and Adolescents with Attention-Deficit/Hyperactivity Disorder: A Comprehensive Review of Over a Decade of Research. CNS Drugs 2016, 30, 603-628. [CrossRef] [PubMed]

24. Faraone, S.V.; Perlis, R.H.; Doyle, A.E.; Smoller, J.W.; Goralnick, J.J.; Holmgren, M.A.; Sklar, P. Molecular genetics of attention-deficit/hyperactivity disorder. Biol. Psychiatry 2005, 57, 1313-1323. [CrossRef] [PubMed]

25. Palladino, V.S.; McNeill, R.; Reif, A.; Kittel-Schneider, S. Genetic risk factors and gene-environment interactions in adult and childhood attention-deficit/hyperactivity disorder. Psychiatr. Genet. 2019, 29, 63-78. [CrossRef] [PubMed]

26. Thapar, A. Discoveries on the Genetics of ADHD in the 21st Century: New Findings and Their Implications. Am. J. Psychiatry 2018, 175, 943-950. [CrossRef]

27. Martin, J.; O’Donovan, M.C.; Thapar, A.; Langley, K.; Williams, N. The relative contribution of common and rare genetic variants to ADHD. Transl. Psychiatry 2015, 5, e506. [CrossRef]

28. Franke, B.; Faraone, S.V.; Asherson, P.; Buitelaar, J.; Bau, C.H.; Ramos-Quiroga, J.A.; Mick, E.; Grevet, E.H.; Johansson, S.; Haavik, J.; et al. The genetics of attention deficit/hyperactivity disorder in adults, a review. Mol. Psychiatry 2012, 17, 960-987. [CrossRef]

29. Nigg, J.T.; Elmore, A.L.; Natarajan, N.; Friderici, K.H.; Nikolas, M.A. Variation in an Iron Metabolism Gene Moderates the Association Between Blood Lead Levels and Attention-Deficit/Hyperactivity Disorder in Children. Psychol. Sci. 2016, 27, 257-269. [CrossRef]

30. Nigg, J.T.; Breslau, N. Prenatal smoking exposure, low birth weight, and disruptive behavior disorders. J. Am. Acad. Child. Adolesc. Psychiatry 2007, 46, 362-369. [CrossRef] 
31. Knopik, V.S.; Sparrow, E.P.; Madden, P.A.; Bucholz, K.K.; Hudziak, J.J.; Reich, W.; Slutske, W.S.; Grant, J.D.; McLaughlin, T.L.; Todorov, A.; et al. Contributions of parental alcoholism, prenatal substance exposure, and genetic transmission to child ADHD risk: A female twin study. Psychol. Med. 2005, 35, 625-635. [CrossRef] [PubMed]

32. Genro, J.P.; Kieling, C.; Rohde, L.A.; Hutz, M.H. Attention-deficit/hyperactivity disorder and the dopaminergic hypotheses. Expert Rev. Neurother. 2010, 10, 587-601. [CrossRef]

33. Swanson, J.M.; Kinsbourne, M.; Nigg, J.; Lanphear, B.; Stefanatos, G.A.; Volkow, N.; Taylor, E.; Casey, B.J.; Castellanos, F.X.; Wadhwa, P.D. Etiologic subtypes of attention-deficit/hyperactivity disorder: Brain imaging, molecular genetic and environmental factors and the dopamine hypothesis. Neuropsychol. Rev. 2007, 17, 39-59. [CrossRef] [PubMed]

34. Del Campo, N.; Chamberlain, S.R.; Sahakian, B.J.; Robbins, T.W. The roles of dopamine and noradrenaline in the pathophysiology and treatment of attention-deficit/hyperactivity disorder. Biol. Psychiatry 2011, 69, e145-e157. [CrossRef] [PubMed]

35. Prince, J. Catecholamine dysfunction in attention-deficit/hyperactivity disorder: An update. J. Clin. Psychopharmacol. 2008, 28, S39-S45. [CrossRef]

36. Lopresti, A.L. Oxidative and nitrosative stress in ADHD: Possible causes and the potential of antioxidant-targeted therapies. Atten. Defic. Hyperact. Dis. 2015, 7, 237-247. [CrossRef] [PubMed]

37. Joseph, N.; Zhang-James, Y.; Perl, A.; Faraone, S.V. Oxidative Stress and ADHD: A Meta-Analysis. J. Atten. Dis. 2015, 19, 915-924. [CrossRef]

38. Instanes, J.T.; Halmoy, A.; Engeland, A.; Haavik, J.; Furu, K.; Klungsoyr, K. Attention-Deficit/Hyperactivity Disorder in Offspring of Mothers With Inflammatory and Immune System Diseases. Biol. Psychiatry 2017, 81, 452-459. [CrossRef]

39. Dunn, G.A.; Nigg, J.T.; Sullivan, E.L. Neuroinflammation as a risk factor for attention deficit hyperactivity disorder. Pharm. Biochem. Behav. 2019, 182, 22-34. [CrossRef]

40. Leffa, D.T.; Torres, I.L.S.; Rohde, L.A. A Review on the Role of Inflammation in Attention-Deficit/Hyperactivity Disorder. Neuroimmunomodulation 2018, 25, 328-333. [CrossRef]

41. Cobley, J.N.; Fiorello, M.L.; Bailey, D.M. 13 reasons why the brain is susceptible to oxidative stress. Redox Biol. 2018, 15, 490-503. [CrossRef] [PubMed]

42. Singh, E.; Devasahayam, G. Neurodegeneration by oxidative stress: A review on prospective use of small molecules for neuroprotection. Mol. Biol. Rep. 2020, 47, 3133-3140. [CrossRef] [PubMed]

43. Corona, J.C.; Duchen, M.R. Impaired mitochondrial homeostasis and neurodegeneration: Towards new therapeutic targets? J. Bioenerg. Biomembr. 2015, 47, 89-99. [CrossRef]

44. Moniczewski, A.; Gawlik, M.; Smaga, I.; Niedzielska, E.; Krzek, J.; Przegalinski, E.; Pera, J.; Filip, M. Oxidative stress as an etiological factor and a potential treatment target of psychiatric disorders. Part 1. Chemical aspects and biological sources of oxidative stress in the brain. Pharm. Rep. 2015, 67, 560-568. [CrossRef]

45. Smaga, I.; Niedzielska, E.; Gawlik, M.; Moniczewski, A.; Krzek, J.; Przegalinski, E.; Pera, J.; Filip, M. Oxidative stress as an etiological factor and a potential treatment target of psychiatric disorders. Part 2. Depression, anxiety, schizophrenia and autism. Pharm. Rep. 2015, 67, 569-580. [CrossRef]

46. Weng, M.; Xie, X.; Liu, C.; Lim, K.L.; Zhang, C.W.; Li, L. The Sources of Reactive Oxygen Species and Its Possible Role in the Pathogenesis of Parkinson's Disease. Parkinsons Dis. 2018, 2018, 9163040. [CrossRef]

47. de Araujo Boleti, A.P.; de Oliveira Flores, T.M.; Moreno, S.E.; Anjos, L.D.; Mortari, M.R.; Migliolo, L. Neuroinflammation: An overview of neurodegenerative and metabolic diseases and of biotechnological studies. Neurochem. Int. 2020, 136, 104714. [CrossRef]

48. Solleiro-Villavicencio, H.; Rivas-Arancibia, S. Effect of Chronic Oxidative Stress on Neuroinflammatory Response Mediated by CD4 ${ }^{+}$T Cells in Neurodegenerative Diseases. Front. Cell. Neurosci. 2018, 12, 114. [CrossRef]

49. Ross, B.M.; McKenzie, I.; Glen, I.; Bennett, C.P. Increased levels of ethane, a non-invasive marker of n-3 fatty acid oxidation, in breath of children with attention deficit hyperactivity disorder. Nutr. Neurosci. 2003, 6, 277-281. [CrossRef] [PubMed]

50. Bulut, M.; Selek, S.; Gergerlioglu, H.S.; Savas, H.A.; Yilmaz, H.R.; Yuce, M.; Ekici, G. Malondialdehyde levels in adult attention-deficit hyperactivity disorder. J. Psychiatry Neurosci. 2007, 32, 435-438. 
51. Bulut, M.; Selek, S.; Bez, Y.; Cemal Kaya, M.; Gunes, M.; Karababa, F.; Celik, H.; Savas, H.A. Lipid peroxidation markers in adult attention deficit hyperactivity disorder: New findings for oxidative stress. Psychiatry Res. 2013, 209, 638-642. [CrossRef] [PubMed]

52. Chovanova, Z.; Muchova, J.; Sivonova, M.; Dvorakova, M.; Zitnanova, I.; Waczulikova, I.; Trebaticka, J.; Skodacek, I.; Durackova, Z. Effect of polyphenolic extract, Pycnogenol, on the level of 8-oxoguanine in children suffering from attention deficit/hyperactivity disorder. Free Radic. Res. 2006, 40, 1003-1010. [CrossRef] [PubMed]

53. Ceylan, M.; Sener, S.; Bayraktar, A.C.; Kavutcu, M. Oxidative imbalance in child and adolescent patients with attention-deficit/hyperactivity disorder. Prog. Neuropsychopharmacol. Biol. Psychiatry 2010, 34, 1491-1494. [CrossRef]

54. Kawatani, M.; Tsukahara, H.; Mayumi, M. Evaluation of oxidative stress status in children with pervasive developmental disorder and attention deficit hyperactivity disorder using urinary-specific biomarkers. Redox Rep. 2011, 16, 45-46. [CrossRef]

55. Ceylan, M.F.; Sener, S.; Bayraktar, A.C.; Kavutcu, M. Changes in oxidative stress and cellular immunity serum markers in attention-deficit/hyperactivity disorder. Psychiatry Clin. Neurosci. 2012, 66, 220-226. [CrossRef]

56. Oztop, D.; Altun, H.; Baskol, G.; Ozsoy, S. Oxidative stress in children with attention deficit hyperactivity disorder. Clin. Biochem. 2012, 45, 745-748. [CrossRef]

57. Spahis, S.; Vanasse, M.; Belanger, S.A.; Ghadirian, P.; Grenier, E.; Levy, E. Lipid profile, fatty acid composition and pro- and anti-oxidant status in pediatric patients with attention-deficit/hyperactivity disorder. Prostaglandins Leukot. Essent. Fat. Acids 2008, 79, 47-53. [CrossRef]

58. Selek, S.; Bulut, M.; Ocak, A.R.; Kalenderoglu, A.; Savas, H.A. Evaluation of total oxidative status in adult attention deficit hyperactivity disorder and its diagnostic implications. J. Psychiatr. Res. 2012, 46, 451-455. [CrossRef]

59. Kul, M.; Unal, F.; Kandemir, H.; Sarkarati, B.; Kilinc, K.; Kandemir, S.B. Evaluation of Oxidative Metabolism in Child and Adolescent Patients with Attention Deficit Hyperactivity Disorder. Psychiatry Investig. 2015, 12, 361-366. [CrossRef]

60. Guney, E.; Cetin, F.H.; Alisik, M.; Tunca, H.; Tas Torun, Y.; Iseri, E.; Isik Taner, Y.; Cayci, B.; Erel, O. Attention Deficit Hyperactivity Disorder and oxidative stress: A short term follow up study. Psychiatry Res. 2015, 229, 310-317. [CrossRef]

61. Sezen, H.; Kandemir, H.; Savik, E.; Basmaci Kandemir, S.; Kilicaslan, F.; Bilinc, H.; Aksoy, N. Increased oxidative stress in children with attention deficit hyperactivity disorder. Redox Rep. 2016, 21, 248-253. [CrossRef]

62. Karababa, I.F.; Savas, S.N.; Selek, S.; Cicek, E.; Cicek, E.I.; Asoglu, M.; Bayazit, H.; Kandemir, H.; Kati, M.; Ulas, T. Homocysteine Levels and Oxidative Stress Parameters in Patients With Adult ADHD. J. Atten. Dis. 2017, 21, 487-493. [CrossRef]

63. Leffa, D.T.; Bellaver, B.; de Oliveira, C.; de Macedo, I.C.; de Freitas, J.S.; Grevet, E.H.; Caumo, W.; Rohde, L.A.; Quincozes-Santos, A.; Torres, I.L.S. Increased Oxidative Parameters and Decreased Cytokine Levels in an Animal Model of Attention-Deficit/Hyperactivity Disorder. Neurochem. Res. 2017, 42, 3084-3092. [CrossRef]

64. Nasim, S.; Naeini, A.A.; Najafi, M.; Ghazvini, M.; Hassanzadeh, A. Relationship between Antioxidant Status and Attention Deficit Hyperactivity Disorder among Children. Int. J. Prev. Med. 2019, 10, 41.

65. Verlaet, A.A.J.; Breynaert, A.; Ceulemans, B.; De Bruyne, T.; Fransen, E.; Pieters, L.; Savelkoul, H.F.J.; Hermans, N. Oxidative stress and immune aberrancies in attention-deficit/hyperactivity disorder (ADHD): A case-control comparison. Eur. Child. Adolesc. Psychiatry 2019, 28, 719-729. [CrossRef]

66. Kozlowska, A.; Wojtacha, P.; Rowniak, M.; Kolenkiewicz, M.; Huang, A.C.W. ADHD pathogenesis in the immune, endocrine and nervous systems of juvenile and maturating SHR and WKY rats. Psychopharmacology 2019, 236, 2937-2958. [CrossRef] [PubMed]

67. Kitaoka, T.; Morimoto, M.; Hashimoto, T.; Tsuda, Y.; Nakatsu, T.; Kyotani, S. Evaluation of the efficacy of drug treatment based on measurement of the oxidative stress, using reactive oxygen metabolites and biological antioxidant potential, in children with autism spectrum disorder and attention deficit hyperactivity disorder. J. Pharm. Health Care Sci. 2020, 6, 8. [CrossRef]

68. Avcil, S.; Uysal, P.; Yenisey, C.; Abas, B.I. Elevated Melatonin Levels in Children with Attention Deficit Hyperactivity Disorder: Relationship to Oxidative and Nitrosative Stress. J. Atten. Dis. 2019. [CrossRef] 
69. Aspide, R.; Gironi Carnevale, U.A.; Sergeant, J.A.; Sadile, A.G. Non-selective attention and nitric oxide in putative animal models of Attention-Deficit Hyperactivity Disorder. Behav. Brain Res. 1998, 95, 123-133. [CrossRef]

70. Varol Tas, F.; Guvenir, T.; Tas, G.; Cakaloz, B.; Ormen, M. Nitric oxide levels in disruptive behavioral disorder. Neuropsychobiology 2006, 53, 176-180. [CrossRef]

71. Selek, S.; Savas, H.A.; Gergerlioglu, H.S.; Bulut, M.; Yilmaz, H.R. Oxidative imbalance in adult attention deficit/hyperactivity disorder. Biol. Psychol. 2008, 79, 256-259. [CrossRef] [PubMed]

72. Swanson, C.J.; Perry, K.W.; Koch-Krueger, S.; Katner, J.; Svensson, K.A.; Bymaster, F.P. Effect of the attention deficit/hyperactivity disorder drug atomoxetine on extracellular concentrations of norepinephrine and dopamine in several brain regions of the rat. Neuropharmacology 2006, 50, 755-760. [CrossRef] [PubMed]

73. Martins, M.R.; Reinke, A.; Petronilho, F.C.; Gomes, K.M.; Dal-Pizzol, F.; Quevedo, J. Methylphenidate treatment induces oxidative stress in young rat brain. Brain Res. 2006, 1078, 189-197. [CrossRef] [PubMed]

74. Andreazza, A.C.; Frey, B.N.; Valvassori, S.S.; Zanotto, C.; Gomes, K.M.; Comim, C.M.; Cassini, C.; Stertz, L.; Ribeiro, L.C.; Quevedo, J.; et al. DNA damage in rats after treatment with methylphenidate. Prog. Neuropsychopharmacol. Biol. Psychiatry 2007, 31, 1282-1288. [CrossRef]

75. Fagundes, A.O.; Rezin, G.T.; Zanette, F.; Grandi, E.; Assis, L.C.; Dal-Pizzol, F.; Quevedo, J.; Streck, E.L. Chronic administration of methylphenidate activates mitochondrial respiratory chain in brain of young rats. Int. J. Dev. Neurosci. 2007, 25, 47-51. [CrossRef]

76. Gomes, K.M.; Inacio, C.G.; Valvassori, S.S.; Reus, G.Z.; Boeck, C.R.; Dal-Pizzol, F.; Quevedo, J. Superoxide production after acute and chronic treatment with methylphenidate in young and adult rats. Neurosci. Lett. 2009, 465, 95-98. [CrossRef]

77. Schmitz, F.; Scherer, E.B.; Machado, F.R.; da Cunha, A.A.; Tagliari, B.; Netto, C.A.; Wyse, A.T. Methylphenidate induces lipid and protein damage in prefrontal cortex, but not in cerebellum, striatum and hippocampus of juvenile rats. Metab. Brain Dis. 2012, 27, 605-612. [CrossRef]

78. Comim, C.M.; Gomes, K.M.; Reus, G.Z.; Petronilho, F.; Ferreira, G.K.; Streck, E.L.; Dal-Pizzol, F.; Quevedo, J. Methylphenidate treatment causes oxidative stress and alters energetic metabolism in an animal model of attention-deficit hyperactivity disorder. Acta Neuropsychiatr. 2014, 26, 96-103. [CrossRef]

79. Motaghinejad, M.; Motevalian, M.; Shabab, B.; Fatima, S. Effects of acute doses of methylphenidate on inflammation and oxidative stress in isolated hippocampus and cerebral cortex of adult rats. J. Neural. Transm. (Vienna) 2017, 124, 121-131. [CrossRef]

80. Corona, J.C.; Carreon-Trujillo, S.; Gonzalez-Perez, R.; Gomez-Bautista, D.; Vazquez-Gonzalez, D.; Salazar-Garcia, M. Atomoxetine produces oxidative stress and alters mitochondrial function in human neuron-like cells. Sci. Rep. 2019, 9, 13011. [CrossRef]

81. Dutt, M.; Dharavath, R.N.; Kaur, T.; Chopra, K.; Sharma, S. Differential effects of alprazolam against methylphenidate-induced neurobehavioral alterations. Physiol. Behav. 2020, 222, 112935. [CrossRef] [PubMed]

82. Dvorakova, M.; Sivonova, M.; Trebaticka, J.; Skodacek, I.; Waczulikova, I.; Muchova, J.; Durackova, Z. The effect of polyphenolic extract from pine bark, Pycnogenol on the level of glutathione in children suffering from attention deficit hyperactivity disorder (ADHD). Redox. Rep. 2006, 11, 163-172. [CrossRef] [PubMed]

83. Dvorakova, M.; Jezova, D.; Blazicek, P.; Trebaticka, J.; Skodacek, I.; Suba, J.; Iveta, W.; Rohdewald, P.; Durackova, Z. Urinary catecholamines in children with attention deficit hyperactivity disorder (ADHD): Modulation by a polyphenolic extract from pine bark (pycnogenol). Nutr. Neurosci. 2007, 10, 151-157. [CrossRef] [PubMed]

84. Russo, A.J. Decreased Serum Cu/Zn SOD Associated with High Copper in Children with Attention Deficit Hyperactivity Disorder (ADHD). J. Cent. Nerv. Syst. Dis. 2010, 2, 9-14. [CrossRef]

85. El Adham, E.K.; Hassan, A.I.; El Aziz El-Mahdy, A.A. Nutritional and Metabolic Disturbances in Attention Deficit Hyperactivity Disease. Res. J. Med. Med. Sci 2011, 6, 10-16.

86. Ruchi, K.; Anil Kumar, S.; Sunil, G.; Bashir, A.; and Prabhat, S. Antioxidant activity in children with ADHD-A comparison in untreated and treated subjects with normal children. Med. J. Malays. 2011, 10, 31-35.

87. Archana, E.; Pai, P.; Prabhu, B.K.; Shenoy, R.P.; Prabhu, K.; Rao, A. Altered biochemical parameters in saliva of pediatric attention deficit hyperactivity disorder. Neurochem. Res. 2012, 37, 330-334. [CrossRef] 
88. Gomes, K.M.; Petronilho, F.C.; Mantovani, M.; Garbelotto, T.; Boeck, C.R.; Dal-Pizzol, F.; Quevedo, J. Antioxidant enzyme activities following acute or chronic methylphenidate treatment in young rats. Neurochem. Res. 2008, 33, 1024-1027. [CrossRef]

89. Goldstein, D.S.; Kopin, I.J.; Sharabi, Y. Catecholamine autotoxicity. Implications for pharmacology and therapeutics of Parkinson disease and related disorders. Pharmacol. Ther. 2014, 144, 268-282. [CrossRef]

90. Napolitano, A.; Manini, P.; d'Ischia, M. Oxidation chemistry of catecholamines and neuronal degeneration: An update. Curr. Med. Chem. 2011, 18, 1832-1845. [CrossRef] [PubMed]

91. Smythies, J. Redox aspects of signaling by catecholamines and their metabolites. Antioxid. Redox Signal. 2000, 2, 575-583. [CrossRef] [PubMed]

92. Neri, M.; Cerretani, D.; Fiaschi, A.I.; Laghi, P.F.; Lazzerini, P.E.; Maffione, A.B.; Micheli, L.; Bruni, G.; Nencini, C.; Giorgi, G.; et al. Correlation between cardiac oxidative stress and myocardial pathology due to acute and chronic norepinephrine administration in rats. J. Cell. Mol. Med. 2007, 11, 156-170. [CrossRef]

93. Spencer, W.A.; Jeyabalan, J.; Kichambre, S.; Gupta, R.C. Oxidatively generated DNA damage after Cu (II) catalysis of dopamine and related catecholamine neurotransmitters and neurotoxins: Role of reactive oxygen species. Free Radic. Biol. Med. 2011, 50, 139-147. [CrossRef]

94. Stephenson, J.; Nutma, E.; van der Valk, P.; Amor, S. Inflammation in CNS neurodegenerative diseases. Immunology 2018, 154, 204-219. [CrossRef]

95. Waisman, A.; Liblau, R.S.; Becher, B. Innate and adaptive immune responses in the CNS. Lancet Neurol. 2015, 14, 945-955. [CrossRef]

96. Shabab, T.; Khanabdali, R.; Moghadamtousi, S.Z.; Kadir, H.A.; Mohan, G. Neuroinflammation pathways: A general review. Int. J. Neurosci. 2017, 127, 624-633. [CrossRef]

97. Kohman, R.A.; Rhodes, J.S. Neurogenesis, inflammation and behavior. Brain Behav. Immun. 2013, $27,22-32$. [CrossRef]

98. Ni Chasaide, C.; Lynch, M.A. The role of the immune system in driving neuroinflammation. Brain Neurosci. Adv. 2020, 4, 2398212819901082. [CrossRef]

99. Yong, H.Y.F.; Rawji, K.S.; Ghorbani, S.; Xue, M.; Yong, V.W. The benefits of neuroinflammation for the repair of the injured central nervous system. Cell. Mol. Immunol. 2019, 16, 540-546. [CrossRef]

100. Matta, S.M.; Hill-Yardin, E.L.; Crack, P.J. The influence of neuroinflammation in Autism Spectrum Disorder. Brain Behav. Immun. 2019, 79, 75-90. [CrossRef]

101. Benedetti, F.; Aggio, V.; Pratesi, M.L.; Greco, G.; Furlan, R. Neuroinflammation in Bipolar Depression. Front. Psychiatry 2020, 11, 71. [CrossRef]

102. Cernackova, A.; Durackova, Z.; Trebaticka, J.; Mravec, B. Neuroinflammation and depressive disorder: The role of the hypothalamus. J. Clin. Neurosci. 2020, 75, 5-10. [CrossRef] [PubMed]

103. Buckley, P.F. Neuroinflammation and Schizophrenia. Curr. Psychiatry Rep. 2019, 21, 72. [CrossRef] [PubMed]

104. Oades, R.D.; Dauvermann, M.R.; Schimmelmann, B.G.; Schwarz, M.J.; Myint, A.M. Attention-deficit hyperactivity disorder (ADHD) and glial integrity: S100B, cytokines and kynurenine metabolism—Effects of medication. Behav. Brain Funct. 2010, 6, 29. [CrossRef]

105. Oades, R.D.; Myint, A.M.; Dauvermann, M.R.; Schimmelmann, B.G.; Schwarz, M.J. Attention-deficit hyperactivity disorder (ADHD) and glial integrity: An exploration of associations of cytokines and kynurenine metabolites with symptoms and attention. Behav. Brain Funct. 2010, 6, 32. [CrossRef] [PubMed]

106. Siracusa, R.; Fusco, R.; Cuzzocrea, S. Astrocytes: Role and Functions in Brain Pathologies. Front. Pharm. 2019, 10, 1114. [CrossRef] [PubMed]

107. Sandau, U.S.; Alderman, Z.; Corfas, G.; Ojeda, S.R.; Raber, J. Astrocyte-specific disruption of SynCAM1 signaling results in ADHD-like behavioral manifestations. PLoS ONE 2012, 7, e36424. [CrossRef]

108. Buske-Kirschbaum, A.; Schmitt, J.; Plessow, F.; Romanos, M.; Weidinger, S.; Roessner, V. Psychoendocrine and psychoneuroimmunological mechanisms in the comorbidity of atopic eczema and attention deficit/hyperactivity disorder. Psychoneuroendocrinology 2013, 38, 12-23. [CrossRef]

109. Darwish, A.H.; Elgohary, T.M.; Nosair, N.A. Serum Interleukin-6 Level in Children with Attention-Deficit Hyperactivity Disorder (ADHD). J. Child. Neurol. 2019, 34, 61-67. [CrossRef]

110. Chang, J.P.; Mondelli, V.; Satyanarayanan, S.K.; Chiang, Y.J.; Chen, H.T.; Su, K.P.; Pariante, C.M. Cortisol, inflammatory biomarkers and neurotrophins in children and adolescents with attention deficit hyperactivity disorder (ADHD) in Taiwan. Brain Behav. Immun. 2020. [CrossRef] 
111. Segman, R.H.; Meltzer, A.; Gross-Tsur, V.; Kosov, A.; Frisch, A.; Inbar, E.; Darvasi, A.; Levy, S.; Goltser, T.; Weizman, A.; et al. Preferential transmission of interleukin-1 receptor antagonist alleles in attention deficit hyperactivity disorder. Mol. Psychiatry 2002, 7, 72-74. [CrossRef] [PubMed]

112. Misener, V.L.; Schachar, R.; Ickowicz, A.; Malone, M.; Roberts, W.; Tannock, R.; Kennedy, J.L.; Pathare, T.; Barr, C.L. Replication test for association of the IL-1 receptor antagonist gene, IL1RN, with attention-deficit/hyperactivity disorder. Neuropsychobiology 2004, 50, 231-234. [CrossRef]

113. Drtilkova, I.; Sery, O.; Theiner, P.; Uhrova, A.; Zackova, M.; Balastikova, B.; Znojil, V. Clinical and molecular-genetic markers of ADHD in children. Neuro Endocrinol. Lett. 2008, 29, 320-327.

114. Ribases, M.; Hervas, A.; Ramos-Quiroga, J.A.; Bosch, R.; Bielsa, A.; Gastaminza, X.; Fernandez-Anguiano, M.; Nogueira, M.; Gomez-Barros, N.; Valero, S.; et al. Association study of 10 genes encoding neurotrophic factors and their receptors in adult and child attention-deficit/hyperactivity disorder. Biol. Psychiatry 2008, 63, 935-945. [CrossRef] [PubMed]

115. Smith, T.F.; Anastopoulos, A.D.; Garrett, M.E.; Arias-Vasquez, A.; Franke, B.; Oades, R.D.; Sonuga-Barke, E.; Asherson, P.; Gill, M.; Buitelaar, J.K.; et al. Angiogenic, neurotrophic, and inflammatory system SNPs moderate the association between birth weight and ADHD symptom severity. Am. J. Med. Genet. B Neuropsychiatr. Genet. 2014, 165B, 691-704. [CrossRef]

116. Fasmer, O.B.; Riise, T.; Eagan, T.M.; Lund, A.; Dilsaver, S.C.; Hundal, O.; Oedegaard, K.J. Comorbidity of asthma with ADHD. J. Atten. Dis. 2011, 15, 564-571. [CrossRef]

117. Passarelli, F.; Donfrancesco, R.; Nativio, P.; Pascale, E.; Di Trani, M.; Patti, A.M.; Vulcano, A.; Gozzo, P.; Villa, M.P. Anti-Purkinje cell antibody as a biological marker in attention deficit/hyperactivity disorder: A pilot study. J. Neuroimmunol. 2013, 258, 67-70. [CrossRef] [PubMed]

118. Schmitt, J.; Romanos, M.; Schmitt, N.M.; Meurer, M.; Kirch, W. Atopic eczema and attention-deficit/ hyperactivity disorder in a population-based sample of children and adolescents. JAMA 2009, 301, 724-726. [CrossRef]

119. Genuneit, J.; Braig, S.; Brandt, S.; Wabitsch, M.; Florath, I.; Brenner, H.; Rothenbacher, D. Infant atopic eczema and subsequent attention-deficit/hyperactivity disorder-a prospective birth cohort study. Pediatr. Allergy Immunol. 2014, 25, 51-56. [CrossRef]

120. Chen, Q.; Sjolander, A.; Langstrom, N.; Rodriguez, A.; Serlachius, E.; D'Onofrio, B.M.; Lichtenstein, P.; Larsson, H. Maternal pre-pregnancy body mass index and offspring attention deficit hyperactivity disorder: A population-based cohort study using a sibling-comparison design. Int. J. Epidemiol. 2014, 43, 83-90. [CrossRef]

121. Rivera, H.M.; Christiansen, K.J.; Sullivan, E.L. The role of maternal obesity in the risk of neuropsychiatric disorders. Front. Neurosci. 2015, 9, 194. [CrossRef] [PubMed]

122. Toto, M.; Margari, F.; Simone, M.; Craig, F.; Petruzzelli, M.G.; Tafuri, S.; Margari, L. Antibasal Ganglia Antibodies and Antistreptolysin O in Noncomorbid ADHD. J. Atten. Dis. 2015, 19, 965-970. [CrossRef] [PubMed]

123. Peterson, B.S.; Leckman, J.F.; Tucker, D.; Scahill, L.; Staib, L.; Zhang, H.; King, R.; Cohen, D.J.; Gore, J.C.; Lombroso, P. Preliminary findings of antistreptococcal antibody titers and basal ganglia volumes in tic, obsessive-compulsive, and attention deficit/hyperactivity disorders. Arch. Gen. Psychiatry 2000, 57, 364-372. [CrossRef] [PubMed]

124. Giana, G.; Romano, E.; Porfirio, M.C.; D'Ambrosio, R.; Giovinazzo, S.; Troianiello, M.; Barlocci, E.; Travaglini, D.; Granstrem, O.; Pascale, E.; et al. Detection of auto-antibodies to DAT in the serum: Interactions with DAT genotype and psycho-stimulant therapy for ADHD. J. Neuroimmunol. 2015, 278, 212-222. [CrossRef]

125. Donfrancesco, R.; Nativio, P.; Di Benedetto, A.; Villa, M.P.; Andriola, E.; Melegari, M.G.; Cipriano, E.; Di Trani, M. Anti-Yo Antibodies in Children With ADHD: First Results About Serum Cytokines. J. Atten. Dis. 2016. [CrossRef] [PubMed]

126. Chen, M.H.; Su, T.P.; Chen, Y.S.; Hsu, J.W.; Huang, K.L.; Chang, W.H.; Chen, T.J.; Bai, Y.M. Comorbidity of Allergic and Autoimmune Diseases Among Patients with ADHD. J. Atten. Dis. 2017, 21, 219-227. [CrossRef] [PubMed]

127. Nielsen, P.R.; Benros, M.E.; Dalsgaard, S. Associations between Autoimmune Diseases and Attention-Deficit/Hyperactivity Disorder: A Nationwide Study. J. Am. Acad. Child. Adolesc. Psychiatry 2017, 56, 234-240. [CrossRef] [PubMed] 
128. Brawley, A.; Silverman, B.; Kearney, S.; Guanzon, D.; Owens, M.; Bennett, H.; Schneider, A. Allergic rhinitis in children with attention-deficit/hyperactivity disorder. Ann. Allergy Asthma Immunol. 2004, 92, 663-667. [CrossRef]

129. hen, M.H.; Su, T.P.; Chen, Y.S.; Hsu, J.W.; Huang, K.L.; Chang, W.H.; Bai, Y.M. Attention deficit hyperactivity disorder, tic disorder, and allergy: Is there a link? A nationwide population-based study. J. Child. Psychol. Psychiatry 2013, 54, 545-551.

130. Tsai, J.D.; Chang, S.N.; Mou, C.H.; Sung, F.C.; Lue, K.H. Association between atopic diseases and attention-deficit/hyperactivity disorder in childhood: A population-based case-control study. Ann. Epidemiol. 2013, 23, 185-188. [CrossRef]

131. Wang, L.J.; Yu, Y.H.; Fu, M.L.; Yeh, W.T.; Hsu, J.L.; Yang, Y.H.; Chen, W.J.; Chiang, B.L.; Pan, W.H. Attention deficit-hyperactivity disorder is associated with allergic symptoms and low levels of hemoglobin and serotonin. Sci. Rep. 2018, 8, 10229. [CrossRef] [PubMed]

132. Yang, C.F.; Yang, C.C.; Wang, I.J. Association between allergic diseases, allergic sensitization and attention-deficit/hyperactivity disorder in children: A large-scale, population-based study. J. Chin. Med. Assoc. 2018, 81, 277-283. [CrossRef]

133. Zhu, Z.; Zhu, X.; Liu, C.L.; Shi, H.; Shen, S.; Yang, Y.; Hasegawa, K.; Camargo, C.A.; Liang, L. Shared Genetics of Asthma and Mental Health Disorders: A Large-Scale Genome-Wide Cross-Trait Analysis. Eur. Respir. J. 2019. [CrossRef]

134. Chudal, R.; Brown, A.S.; Gyllenberg, D.; Hinkka-Yli-Salomaki, S.; Sucksdorff, M.; Surcel, H.M.; Upadhyaya, S.; Sourander, A. Maternal serum C-reactive protein (CRP) and offspring attention deficit hyperactivity disorder (ADHD). Eur. Child. Adolesc. Psychiatry 2020, 29, 239-247. [CrossRef] [PubMed]

135. Moghadas, M.; Essa, M.M.; Ba-Omar, T.; Al-Shehi, A.; Qoronfleh, M.W.; Eltayeb, E.A.; Guillemin, G.J.; Manivasagam, T.; Justin-Thenmozhi, A.; Al-Bulushi, B.S.; et al. Antioxidant therapies in attention deficit hyperactivity disorder. Front. Biosci. 2019, 24, 313-333.

136. Verlaet, A.A.J.; Maasakkers, C.M.; Hermans, N.; Savelkoul, H.F.J. Rationale for Dietary Antioxidant Treatment of ADHD. Nutrients 2018, 10, 405. [CrossRef]

137. Richardson, A.J. Omega-3 fatty acids in ADHD and related neurodevelopmental disorders. Int. Rev. Psychiatry 2006, 18, 155-172. [CrossRef]

Publisher's Note: MDPI stays neutral with regard to jurisdictional claims in published maps and institutional affiliations.

(C) 2020 by the author. Licensee MDPI, Basel, Switzerland. This article is an open access article distributed under the terms and conditions of the Creative Commons Attribution (CC BY) license (http://creativecommons.org/licenses/by/4.0/). 